\title{
Methods and Motivations for Studying the Vernacular Linguistic Past
}

Twelfth-century authors inherited a range of biblical, classical and insular models for considering language history. Discussions of sacred languages often sought to elucidate the eternal, searching lexis for traces of the divine. As post-Conquest historical imperatives quickened a desire for vernacular evidence, the exegetical paradigms of the tres linguae sacrae were more fully extended to other types of linguistic data. The application of these paradigms to sources and lexis shaped by the ephemerality of vernacular language created alternative perspectives on the value of the transient. Such evidence could still be used in attempts to reconstruct the truths embodied in language by God at Eden (in many etymologies), or as an eternal witness to divine glory through the possession of land (in many charters). However, at other times, authors focussed more on recovering a given historical moment than on divine intention. Through the lens of a single text, this chapter examines how the impermanence of the vernacular reshaped the parameters of two key methods for portraying language change: etymology and the discovery of archaic source materials.

The evocation or imitation of ancient documents in the languages of preConquest Britain presented an obvious means for substantiating portrayals of history. Uncertainties about ownership and tradition arising from the Norman Conquest had accelerated interest in the demonstration of institutional entitlement. In the main, convincing evidence came from documentation, both genuine and forged: this emphasis on writing drew attention to the importance of old manuscripts, and sometimes to the linguistic detail of charter diplomatic. The bilingual, sophisticated scribal traditions of AngloSaxon England influenced the direction of later attempts at archival preservation and manipulation. Latin was the language of Anglo-Saxon diplomas (royal charters recording perpetual grants of land): the scope and authority of these prestigious documents attracted intense attention in subsequent attempts to defend monastic privileges through copying, embellishment or forgery. The types of document written in English often made less 
comprehensive bids for property and rights, and were hence less susceptible to later alterations: in the pre-Conquest era, the language tended to be employed in private documents like wills and leases. However, information preserved in English still repaid careful consideration from post-Conquest readers. In the pre-Conquest archive, it was used in boundary clauses and in sealed royal writs (where the king alerted officials and interested parties to new grants of land, property or privilege). Responses to language history were not shaped by forgery alone: any post-Conquest assessment of existing Anglo-Saxon records (in Latin or in English) necessitated close engagement with the writing strategies of previous centuries. Given the vernacular focus of this volume, treatments of Old English documents will be examined in more depth here than Latin ones; however, both languages offered readers substantial and mutually complementary opportunities to incorporate archival evidence within depictions of institutional history.

Interest in the material evidence of Old English also stimulated broader enquiries into how the vernacular could be employed to locate texts in geographically and temporally specific contexts. Even as it encouraged increasingly nuanced depictions of the written word, the use of vernacular evidence also entailed a return to oral sources. Late antique methods of Latin etymology offered an important template for the recovery of lost contexts through language, but unlike Latin, later forms of the vernacular continued to be spoken by the island's twelfth-century population. This created a subtle challenge to textual and social hierarchies: for place names, the linguistic knowledge inherited by peasants from their forefathers often outweighed other forms of authority.

Here, these concerns will be explored through an examination of the role played by vernacular language in the spectacularly successful manipulation of archival material at the Benedictine monastery of St Albans after the Norman Conquest. After a brief excursus on the place of Old English documentation within the monks' wider arguments for exemptions and privileges, the chapter turns to two episodes in the Gesta Abbatum Monasterii Sancti Albani, a twelfth- and thirteenth-century chronicle of the abbots of St Albans. The first passage tells of the Anglo-Saxon discovery of a history of Alban's martyrdom in the British language, which dramatically crumbles to dust when translated into Latin. Part of a broader framing of the past within the Gesta Abbatum to combat the abbey's critics, the incident was more a response to the exigencies of contemporary polemic than a factual narrative. Although its concerns were germane to the wider emphasis on written testimony at St Albans, the text was self-conscious in its employment of literary topoi designed to demonstrate the British book's authority. 
A second episode of the Gesta Abbatum employed etymologies drawn from local memory to verify archaeological discovery: it was similarly alert to tensions between the vernacular's potential to provide historical evidence, and the ways in which the recovery of such evidence had been shaped by imagination and desire. It is argued here that these episodes formed an oblique commentary on how the vernacular subtly modified some Latinate standards of linguistic and documentary proof. Unlike the eternal truth embodied in the etymological details of the tres linguae sacrae, the historical value of the vernacular derived from its impermanence in some instances: the unique specificity of its testimony had been shaped by external circumstances of time and place.

\section{Creating Documentary Evidence in English}

Ecclesiastical archives became the object of fresh consideration after the Conquest, in response to the threats posed by the systematic replacement of English bishops by Normans; by the reversion of estates to the king in the event of a vacancy in a bishopric; and by incursions into Church holdings by lay magnates. ${ }^{I}$ Charters, and particularly royal charters, provided the strongest means of demonstrating ownership: in the course of being copied anew, many documents were judiciously interpolated to update or augment existing privilege. The ubiquity of this practice suggests that the defence of monastic property did not merely reflect administrative and pecuniary pressures. Rather, religious institutions sought to secure the present and future glorification of God by ensuring the continuity of their status, holdings, and rights. ${ }^{2}$ Faced with pre-Conquest charters which were inadequate to the increasingly stringent standards of documentary proof required in the twelfth century, many scribes altered them to reflect what they believed would have been the original donors' intentions: although it was understood to be a crime, forgery's status as a sin was more ambiguous. ${ }^{3}$

When they replicated the conventions of Anglo-Saxon documentation, scribes were obliged to pay attention both to its material form, and to the particularity of its phraseology. This entailed a substantial engagement not only with Latin but also with the vernacular at a time when administrative written Old English was gradually becoming more unfamiliar. Soon after the Conquest, royal scribes largely ceased to use the language: probably in I070, Latin became the preferred idiom of William I's writs. ${ }^{4}$ However, the employment of English by Anglo-Saxon kings testified to its previous status: pre-Conquest documents recorded a period when it was a prestigious language of institutional memory. Although the earliest 
Anglo-Saxon charters are preserved in Latin, sealed royal writs appeared in English from at least the reign of Cnut. From the ninth century onwards, English was also used with increasing frequency for private documents, including wills, leases, and other agreements. ${ }^{5}$ In some cases, this reflected the practical necessity of creating records easily understandable by the laity, or of recording an oral statement precisely. ${ }^{6}$ Elsewhere, it entailed a tacit recognition of the particularity of vernacular language. Some of the most prominent forms of Latin charters display an evolving awareness of the value of English. The Latin diplomas which commemorate land grants to the Church feature a boundary clause, outlining the geographical extent of the estate under discussion: the earliest examples appear in the eighth century, where vernacular place names are integrated within Latin compass directions. ${ }^{7}$ By the first half of the ninth century, these clauses were becoming a more involved description of the land in question; perhaps in response to a need for greater specificity, some began to be composed entirely in English. ${ }^{8}$ By the early tenth century, they stopped being written in Latin at all, and appear exclusively in the vernacular after this point. ${ }^{9}$ When encountered by post-Conquest scribes, the clauses offered an important witness to Anglo-Saxon perceptions of the advantages of the vernacular when discussing regional geography. ${ }^{\mathrm{IO}}$ Ancient, royal, yet local, Old English provided a key model for later readers interested in contesting institutional claims through portrayals of language history.

Approaches to the Latin and vernacular texts within an archive varied widely, and included the copying, adaption, translation, and deletion of material. When shaping archives to meet the demands of contemporary circumstances, textual modification did not necessarily seem out of place: charters were narrative documents, designed to record a preferred version of events which the monastery intended future generations to remember. ${ }^{\text {II }}$ These concerns were manifested in the Liber benefactorum of Ramsey Abbey, which offered one of the fullest twelfth-century discussions of the reasons for archival preservation. The text was produced $c$. II7O in order to provide a permanent memorial to the abbey's benefactors; however, when commemorating their donations, it silently augmented the rights and possessions which they granted to Ramsey. ${ }^{12}$ Citing the anxieties of the Anarchy and the troubled abbacy of Walter (II33-II6O), the compiler aimed to protect the abbey's holdings from future depredations:

Cujus dispersionis, quae rerum fere omnium dissipationem secuta est, nos, utcunque collectae reliquiae, et nubilosa tandem caligine per clementiam divinam in serenitatem conversa, cartarum nostrarum privilegiorum quoque 
et cyrographorum cedulas de antiquitatis strue recollectas, omnes in volumen unum, (quae Anglice scriptae fuerant in Latinum ydioma conversas,) ad cautelam futurorum et legentium notitiam censuimus congerendas. ${ }^{\mathrm{I3}}$

We, the reassembled remnants of that scattering which followed the destruction of nearly everything, have somehow been gathered together. Now that cloudy gloom at last has been turned to fair weather through divine mercy, we have decided to reclaim from the heap of antiquity all the regathered scraps of our charters, privileges and chirographs into one volume (having translated those which were written in English into the Latin language) as a safeguard and account for future readers.

Significantly, the compiler's strategy of archival protection was one of translation, and based on the problems experienced by the community in comprehending Old English. His sensitivity to these difficulties seems to derive from personal experience, but was framed as a response to a legacy of political uncertainty. ${ }^{\mathrm{I}}$ Emphasising the linguistic disruption caused by the Conquest, he stated that 'after the rule of the Normans in England, letters of this kind were less used and less comprehended' ('post dominationem Normannorum in Anglia hujusmodi apices minus usitati, minus cogniti habentur'). ${ }^{15}$ Translating vernacular charters into Latin became an increasingly popular strategy in cartularies, as pre-Conquest English gradually became more distant from twelfth- and thirteenth-century usage (compare British Library, MS Cotton Nero D.i below). However, translation could also provide a veil for archival manipulation. Admitting that some English documents at Ramsey had been lost through age or carelessness, the compiler argued that this was unimportant, as the benefactions they recorded were anyway included in the confirmation charter of Edgar the Peaceable. ${ }^{16}$ As Edgar's charter is forged, the lost documents may not have existed. ${ }^{17}$ They have been invoked not out of a desire for historical accuracy, but in order to augment the authority of the Latin charter: the Liber Benefactorum acknowledged the power of 'extremely old documents written in English' ('vetustissimis scedulis Anglice scriptum') to silence contemporary scepticism. ${ }^{\mathrm{I}}$

In other cases, pre-Conquest English documents were not merely evoked, but created anew. At Bury St Edmunds in the eleventh century, the abbey fabricated a Latin charter of Cnut with an accompanying Old English version in order to claim a significant range of privileges. ${ }^{19}$ These forgeries necessitated a close study of Bury's existing archive: the vernacular text was concocted by borrowing large portions of its phraseology from a bilingual writ of Edward the Confessor. ${ }^{20}$ It may have been intended to 
serve as evidence in a dispute between Abbot Baldwin and the Bishop of East Anglia, which was finally settled in favour of Baldwin in 108I, following his display of written praecepta from Edward and Cnut, amongst others. ${ }^{21}$ It is unclear why an Old English version was thought to be necessary: it may seek to reflect the bilingual form of its model, Edward's writ. ${ }^{22}$ The text illustrates both the attention paid to the language and conventions of vernacular texts, and the forgers' assumptions that English formed an integral part of some pre-Conquest royal charters. ${ }^{23}$ By the twelfth century, it seems that some readers of Bury's vernacular texts felt that authority was transmitted via minute linguistic detail. Richard Sharpe notes the care with which a Latin writ-charter of William Rufus translates the language of its English exemplar from William I: Bury preserved several sequences of these documents, which showed successive kings re-confirming the rights granted by their predecessors to the abbey for the duration of their own reigns. ${ }^{24}$ Although the importance of reproducing the form and content of previous textual models was clear, the writer also attempted a very close replication of the writ-charter's linguistic idiosyncrasies, often producing calques of vernacular idioms. Bury's scriptorium gave its Old English materials unusually intense attention. ${ }^{25}$ However, these scribal interests were also manifested in archives elsewhere to differing degrees. As monasteries attempted to validate privileges via the preservation or fabrication of documentary evidence, they became increasingly sensitive to the potential of Old English (alongside Latin) to embody traditions and rights.

As elsewhere, St Albans abbey sought to protect its possessions in the climate of uncertainty which followed I066: it launched an ambitious campaign with notable success, resulting in a significant rise in its postConquest status and revenues. ${ }^{26}$ The efforts to support or augment the abbey's standing were sustained across a variety of texts and genres, including several works which employ or evoke vernacular documentation. It seems likely that St Albans abbey had a very small pre-Conquest archive: its unsettled early history before its refoundation in the late tenth century probably resulted in the loss of key documents, perhaps aggravated by a failure to preserve a written record of benefactions at the time they were granted. ${ }^{27}$ The surviving charters account for less than half the holdings of the monastery as recorded in the Domesday survey. ${ }^{28}$ These obvious lacuna were a source of concern to its medieval community, and steps were taken to remedy the deficiency. Julia Crick has demonstrated that St Albans in the mid-twelfth century was a centre of 'hands-on antiquarianism': the scriptorium produced a series of forged or interpolated pre-Conquest Latin documents which were designed to demonstrate the monastery's ancient claims 
to exemption from royal and episcopal interference. ${ }^{29}$ As this campaign sought to create supposedly ancient rights anew, as much as to preserve them, St Albans acquired exceptional status by the end of the twelfth century: the geographical boundaries of its liberty were unusually extensive, growing from the zone of exemption of fifteen churches defined in II57 to encompass most of south-west Hertfordshire. ${ }^{30}$ The extent of its jurisdictional immunity was similarly far-reaching: the monastery was exempt from visitation by the Diocesan bishop, had the power to exclude the king's officials, could refuse to pay some taxes, and had various judicial rights. ${ }^{3 \mathrm{I}}$ This self-perception as the rightful holder of an ancient Anglo-Saxon privilege was responsible for a carefully co-ordinated archival programme of the preservation and selective updating of pre-Conquest documents. The community realised the value of their special status, and carefully maintained it through the judicious manipulation of written record.

Old English played a significant role in the presentation of the St Albans archive to the world beyond the monastery, and stimulated a deeper imaginative engagement with the opportunities offered by vernacular data. Aside from three single sheets, our knowledge of all the charters of St Albans now derives from one cartulary, which was completed after 156 and probably before the second quarter of the thirteenth century. ${ }^{32}$ Although the manuscript itself is now lost, its contents can be reconstructed via several sources, the fullest of which is a seventeenth-century Bollandist copy discovered by Simon Keynes. ${ }^{33}$ The lost cartulary offered readers carefully selected windows into St Albans's pre-Conquest history, knowingly or unknowingly using layers of forged material to frame its core contentions. Some of these textual modifications may be the work of the twelfth-century compilers themselves. The cartulary featured three copies of an earlier, forged diploma of the house's founder, King Offa (d.796), two of which were augmented with material from the papal bull of 1156 which definitively created the liberty of St Albans. ${ }^{34}$ In preserving and shaping the archival inheritance of St Albans, the compilers of the lost cartulary directed the abbey's later defenders to texts which connected present privileges to the ancient past. Significantly, they felt that the vernacular offered an important way to make this connection tangible. The lost cartulary featured an unusual amount of Old English material (copied from material earlier than the twelfth century, and very largely genuine); the scribes also retained insular characters in proper names. ${ }^{35}$ Its close attention to language and script formed only one aspect of a broader awareness that material artefacts could provide historical evidence to substantiate the abbey's contentions regarding the priority of its traditions. 
The necessity of replicating, translating or modifying pre-Conquest English material encouraged further experiments with the ways in which the vernacular could encode historical detail. The Gesta Abbatum Monasterii Sancti Albani explores the dialogue between the preservation and augmentation of vernacular evidence which shaped the compilation of monastic archives. It now survives only as part of the Liber additamentorum, produced by Matthew Paris in the mid-I250s: a separate quire now bound with the manuscript contains the charters of the lost cartulary in abbreviated form, which has been annotated in his hand..$^{36}$ Moving away from the attention to Old English displayed in the lost cartulary, Matthew Paris preserved the charters in Latin alone and edited out the vernacular. This probably reflected the same concerns about comprehension shown earlier at Ramsey: a confident reading knowledge of pre-Conquest English was a rare skill by the mid-thirteenth century. However, the versions of the lost cartulary and the Gesta Abbatum in the Liber additamentorum (British Library MS Cotton Nero D.i) both offer Matthew Paris's thirteenthcentury response to the twelfth-century literature of St Albans, and its interest in the vernacular. In the absence of a prior copy of the Gesta Abbatum, it is unclear how far his text altered his earlier sources. Cotton Nero D.i contains a note on the top margin of the opening page, which states that the work was compiled:

Secundum antiquum rotulum Bartholomaei Clerici qui cum Domino Adam Cellarario diu fuerat, serviens ei, et ipsum rotulum sibi retinuit, de scriptis suis hoc solum eligens. ${ }^{37}$

According to the ancient roll of Bartholomew the clerk who was with Adam the Cellarer a long time, serving him, and kept this roll for himself, choosing this one alone from his writings.

Adam was active $c$.II4O-II76, so the roll would already have been old when read by Matthew Paris. ${ }^{38}$ This ambiguously phrased acknowledgement is open to several interpretations, but Mark Hagger has recently made a convincing case that Bartholomew's roll provided the underlying narrative structure for the Gesta Abbatum up to the mid-twelfth century, even if Matthew Paris continued to embellish the text. ${ }^{39}$ Significantly, the lost cartulary also contained material which was connected to the office of the cellarer. The two interpolated copies of the diploma of Offa (discussed above) were incongruously separated from each other by accounts concerning the monks' kitchen, dating from the abbacy of Geoffrey de Gorham (III9-II46);40 information taken from these accounts was also included 
in the Gesta Abbatum's narrative of the time of Geoffrey. ${ }^{4 \mathrm{I}}$ It is hence possible that Adam the Cellarer was involved in the genesis of both works, which shared an interest in the ways that historical forms of the vernacular affirmed broader portrayals of the past. ${ }^{42}$ This complex text offers two layers of responses to the history of St Albans. Firstly, twelfth-century writers gave their perspective on the pre-Conquest period in the source materials for Matthew Paris's Gesta Abbatum. Secondly, Matthew's own version of the text responded to these twelfth-century perceptions, which also reflected his own views of the abbey's early history. Here, both layers will be considered as a whole: although the existing form of the work has doubtless been shaped by Matthew, it is also likely to encode twelfth-century interests in the presentation of the past via ancient language and documents.

Like the cartulary, the Gesta Abbatum attempted to furnish arguments for those wishing to defend the abbey's status, this time in response to threats from Ely and Bishop Robert of Lincoln. ${ }^{43}$ Though the claims it made were prompted by wider imperatives of litigation and prestige, it may have been primarily intended for circulation amongst an internal readership. ${ }^{44}$ If so, then its authors spoke more to a favourably inclined St Albans audience than the house's external critics: this allowed them to move beyond the verifiable and the probable to focus on the desirable. The text sought to strengthen the community's institutional identity by recording an idealised version of its history for future generations; it offered a partisan narrative which often preferred historically alluring scenarios to factual accuracy. Yet we might ask whether the laboured elaborateness of some of these explanations deliberately invited, if not disbelief, then at least a heightened sense of the constructed nature of historical argument. By straining the limits of credibility, the text encouraged readers to consider the tensions and elisions involved in the writing of institutional history, even whilst emphasising the triumphant continuity of St Albans traditions in the face of adversity. The Gesta Abbatum thus becomes a literary space for the dramatisation and dismissal of anxieties concerning the absence of historical proof.

Whilst the lost cartulary replicated the details of its Old English exemplars in order to convince readers that it recorded genuine charters, the Gesta Abbatum created imaginary depictions of the vernacular evidence capable of substantiating its startlingly ambitious historical claims. Two important episodes both related to archaeological investigations into the Roman foundations of the town. A strange blend of the factual and the fantastic, these revealed a disused dragon cave alongside the Roman artefacts which corroborated the existing saints' lives of Alban. The text's idealised portrayals of documentary and etymological vernacular testimony will be 
examined here in order to trace some of the opportunities perceived by twelfth-century writers (in dialogue with Matthew Paris in this instance) when approaching language history.

\section{The Impermanence of Textual Sources}

Issues surrounding evidence, textuality, and belief crystallised in one episode which related the discovery of an ancient book written in British (portrayed by Matthew Paris as occurring in the tenth century). Like much of the Anglo-Saxon material in the Gesta Abbatum, this section was a late elaboration designed to cover significant gaps in the monastic archive. ${ }^{45}$ The narrator stated that in the course of archaeological investigations, a hollow in a wall was found, containing several small books and scrolls, and with them an unknown volume:

[D] um fossores muros et abscondita terrae rimarentur, in medio civitatis antiquae cujusdam magni palatii fundamenta diruerunt, et cum tantorum vestigia aedificiorum admirarentur, invenerunt in cujusdam muri concavo, deposito quasi armariolo cum quibusdam minoribus libris et rotulis, cujusdam codicis ignotum volumen, quod parum fuit ex tam longaeva mora demolitum. Cujus nec littera nec idioma alicui tunc invento cognitum, prae antiquitate, fuerat; venustae tamen formae, et manifestae litterae, fuerat; quarum epigrammata et tituli aureis litteris fulserunt redimiti. Asseres querni, ligamina serica, pristinam in magna parte fortitudinem et decorem retinuerunt. De cujus libri notitia cum multum longe lateque fuerat diligenter inquisitum, tandem unum senem, jam decrepitum, invenerunt sacerdotem, litteris bene eruditum, nomine 'Unwonam': qui, imbutus diversorum idiomatum linguis ac litteris, legit distincte et aperte scripta libri praenominati. ${ }^{46}$

While diggers were investigating the walls and the hidden things of the earth, in the middle of the ancient city they excavated the foundations of a huge palace, and when they were admiring the remains of such large building works, they found in a hollow of a wall, as though left in a book box, with lesser books and rolls, an unknown volume in the form of a codex, which so protracted a space of time was insufficient to destroy. Due to its antiquity, neither its script nor language were known to anyone then found there; however, it was of ancient appearance and clear letter forms; its inscriptions and titles shone, adorned with golden letters. Its oak boards and silken bands largely retained their former strength and beauty. Information about these books was diligently sought far and wide amongst many. At last they found an old, even decrepit, priest, very learned, Unwona by name: who, instructed in the languages and scripts of many different tongues, read clearly and accurately the writings of the aforementioned book. 
The volume was found to contain a history of the protomartyr St Alban, agreeing in all respects with that provided by Bede in the Ecclesiastical History. ${ }^{47}$ As the other books contained pagan rites of Apollo and Mercury, the abbot caused them to be burnt, but consigned the Historia Sancti Albani to the cathedral treasury, where it was translated by Unwona, in order that its events could be disseminated more widely through preaching. Yet this Latin translation superseded the vernacular testimony of the original text, whose obsolescence was soon dramatically indicated:

Cum autem conscripta historia in Latino pluribus, ut jam dictum est, innotuisset, exemplar primitivum ac originale, - quod mirum est dictu, irrestaurabiliter in pulverem subito redactum, cecidit annullatum..$^{48}$

But when the written history in Latin had made itself known to many, as has already been described, the original and primitive exemplar, - a thing marvellous to relate - was suddenly reduced to dust irrevocably, and fell to nothing.

Whilst the episode closely reflects a monastic desire to possess conclusive and permanent written evidence, the status of this evidence is complicated by the literal and figurative instability of the vernacular.

The description of the incident has been shaped by the literary conventions of the Schriftauffindung, a topos which employs the discovery of an old book to support narrative contentions. ${ }^{49}$ Whilst this tells us little about Anglo-Saxon St Albans, it offers much more information about medieval perceptions of the ability of documents to verify history. The account is reminiscent of the biblical depiction of the discovery of the Torah scrolls during the restoration of the Temple in 2 Chronicles 34:I4. Just as this prompts the Israelites to return to the formerly lost teachings of God's laws, the finding of the British text similarly seems to promise renewal through ancient knowledge. Other monasteries also found the trope to be persuasive. While copying the annals up to II2I at Peterborough, the scribe of manuscript E of the Anglo-Saxon Chronicle interpolated a similar story of the discovery of ancient documents under the year 963, which led to the monastery's refoundation by Æthelwold:

Syððon com se biscop Aðelwold to pære mynstre pe wæs gehaten Medeshamstede ðe hwilon wæs fordon fra heðene folce. Ne fand pær nan ping buton ealde weallas 7 wilde wuda; fand pa hidde in pa ealde wealle writes pet Headda abbot heafde ær gewriton: hu Wulfhere kyng 7 Æððlred his broðor hit heafden wroht, 7 hu hi hit freodon wið king 7 wið biscop 7 
wið ealle weoruldpeudom, 7 hu se papa Agatho hit feostnode mid his write 7 se arcebiscop Deusdedit. Leot wircen pa pet mynstre... ${ }^{50}$

Afterwards the bishop Æthelwold came to the monastery which was called Medeshamstede, which was formerly ravaged by heathen people, [and] found nothing there but old walls and wild woods; then found, hidden in the old walls, writings that Abbot Hedde had earlier written, as to how King Wulfhere and Æthelred, his brother, had constructed it, and how they freed it from king, and from bishop, and from all worldly service; and how the pope Agatho confirmed it with his writ - and the archbishop Deusdedit. Then he had the monastery constructed ... ${ }^{\text {st }}$

This intervention was part of a series of twenty passages which aimed to situate the claims of Peterborough's earlier Latin charters within the Chronicle's historical narrative. ${ }^{52}$ The 'writes' of Abbot Hedda apparently refer to a version of the Relatio Hedde Abbatis, which now survives only in Peterborough's earliest cartulary, the Liber Niger, probably dating from the second quarter of the twelfth century. ${ }^{53}$ A 'judiciously constructed origin legend', the Relatio was perhaps produced during the abbacy of Ernulf (IIO7III4).$^{54}$ It purported to be Hedda's seventh-century Latin account of the monastery's foundation $c .654-655$ (thereby placing it earlier than its neighbour, Ely), and was followed by the confirmation of several key privileges in a dossier of 'breathtaking' forgeries. ${ }^{55}$ By creating an entry for Hedda's discovery of the documents, and by translating their contents, the compilers of the Chronicle were participating in the broader integration of the Relatio across Peterborough house histories. ${ }^{56}$ Yet these insertions also exploited the continuous tradition of composition evinced by the Chronicle. The text's ancient origins lent credence to the claims made by the Relatio; its employment of Old English emphasised its connection to the pre-Conquest past.

As at Peterborough, the St Albans Gesta Abbatum employed the discovery of a prestigious vernacular work in order to authenticate the historical contentions of key Latin texts. The account of Alban's martyrdom in the British book was ostensibly confirmed by Bede's Ecclesiastical History. However, the book's authoritative status allowed it, in turn, to provide important confirmation for Bede. The Ecclesiastical History was unequivocal about Alban's status as Romano-British, rather than English, placing his death at the hands of the Romans during the persecutions of Diocletian, and thus ensuring the saint's primacy as the earliest Christian martyr in Britain. ${ }^{57}$ This chronology formed the foundation of the monastery's claims to privilege; but in the later twelfth century, the house's unbroken connection with Alban seemed under threat due to controversy over the 
final resting place of the relics of St Alban. By the composition of the Liber Eliensis in the II70s, Ely's chapter were claiming that the relics had been brought to Ely in secret after the Norman Conquest, and buried next to their own patron saint, Ætheldreða. ${ }^{58}$ Rather than simply refuting these claims, the authors of the Gesta Abbatum inserted a complicated counterstory, asserting that the bones had never left the abbey, and that Ely had merely received a false, decoy set given to them at the time of Cnut's invasion in order to fool the Danes into thinking that Alban's relics had been sent elsewhere. ${ }^{59}$ Further stages of verification were added later in the text. Whilst the account of the recovery of the British book from the ruins of Roman St Albans in the Gesta Abbatum did not testify to the presence of Alban's relics in the twelfth-century monastery, it verified Bede's account of their original burial, lending further weight to the monks' arguments for primacy.

The authors' employment of the vernacular arose from a desire to demonstrate the ancient, yet local roots of Alban's cult, and its unbroken continuity. This was part of a larger interest in setting of the martyrdom, and in the kinds of source texts which might yield information on the subject. Such interest had undoubtedly been stimulated by the appearance of a new history of Britain in the late IIzos, which provided a wealth of previously unknown detail on the island's earliest inhabitants: Geoffrey of Monmouth's Historia regum Britanniae. Importantly, the text explained its deviation from authorities on early Britain such as Bede and Nennius by claiming to be a translation from a new, vernacular source text: 'a very old book in the British tongue' ('Britannici sermonis librum uetustissimum'). ${ }^{60}$ Like many others, those at St Albans saw the text's considerable potential to enhance the status of their own patron saint, both in the details of Geoffrey's narrative, and in his broader use of the British vernacular. In II77, the monks had staged the miraculous recovery of the body of Alban's companion from a burial site on their land at Redbourn, before translating his relics to a shrine within the abbey church. ${ }^{61}$ This new saint, Amphibalus, was a shadowy figure whose name ultimately reflects Geoffrey's misreading of a graecism for 'mantle', either in Gildas or in a now-lost gloss of Bede. ${ }^{62}$ But Geoffrey may also have been making a subtle joke about the saint's provenance: the name can be read as a Greek adjective meaning 'ambiguous' or 'doubtful'. ${ }^{63}$ The St Albans community chose to overlook these incongruities: it seems that the new details on Alban's martyrdom were too appealing to be questioned. Moreover, the putative language of Geoffrey's source fitted well with an increasing post-Conquest stress on Alban as England's earliest martyr. Descriptions of the saint as 
protomartyr Anglorum were augmented to protomartyr Britanniae in postGalfridian texts. ${ }^{64}$ The lost work in the 'British tongue' offered a tempting new perspective on the house's early history, which the monks were eager to emphasise.

Yet this alertness to the potential of ancient Latin and vernacular documents in constructing the past also suggests an unspoken awareness of their significance to enterprises of forgery. It is unclear how far the first monks to promote the cult of Amphibalus were fully convinced by the Historia regum Britanniae. Geoffrey of Monmouth occupied an ambiguous position amongst twelfth-century scholars: whilst many found it expedient to believe in his startling reassessment of Britain's early history, others were more sceptical. ${ }^{65}$ Although highly sensitive to the linguistic nuances of British, the Gesta Abbatum does not necessarily depict its interpretation as an entirely innocent activity. The name chosen for the book's translator, Unwona, emphasised his role as a witness to the miraculous, recalling earlier house traditions. At the same time, it may have pointed subtly to a nexus of concerns about archival research and falsification. It is likely that the authors came across this extremely rare name in some of the abbey's oldest documents. The lost cartulary included Bishop Unwona of Leicester (i.e. Unwano/Unwana, active $c .780$ ) in the witness list of several of the earliest charters from the reigns of Offa and his son Ecgfrith: these confirmed some of the abbey's most important rights. ${ }^{66}$ Unwona's name probably indicates a continental Germanic provenance, and there is no reason to doubt his historical authenticity. ${ }^{67} \mathrm{He}$ remained an influential presence in house histories. The Vitae duorum Offarum is an innovative Latin biography of King Offa II (whom the Gesta Abbatum portrays as the abbey's founder), which explores his links to his ancestor King Offa I (who first vowed to establish the abbey). ${ }^{68}$ It is preserved in Cotton Nero D.i amongst other manuscripts, and may have been written by Matthew Paris or an anonymous twelfth-century author. Here, Unwona is depicted as Offa's chancellor, and a key witness to the miracle which allowed the king first to locate Alban's relics, and then to translate them into a new reliquary. ${ }^{69}$ Yet Unwona's name also had other resonances. There is a small chance that, on the strength of comparison with Welsh un, 'one', it was considered to be a suitable example of British. ${ }^{70}$ However, to English ears, the name was reminiscent of another word: unwon(e), 'unaccustomed, unprecedented'. $7^{71}$ If this drew attention to the rarity of Unwona's linguistic skills, it also signalled the potential artifice of the account. We are invited to overcome any suspicions through faith: the less credible the events seem, the more miraculous the history of the house appears. Our doubts are raised, only 
to be triumphantly quelled by directing us to the might of St Alban, his wonder-working powers, and the monastery's long tradition as a witness to his miracles.

The conspicuously uncertain provenance of Unwona and his British book might encourage us to read this episode as an oblique commentary on the nature of forgery itself. Monika Otter classes the account amidst other twelfth-century Latin narratives of historical and archaeological discovery which invite their own literary decoding:

They seek and find, unearth and open up the historical past, and in that sense describe their own function; they both describe and are the originary moment of their textual communities' self-understanding. ${ }^{72}$

This enactment of self-referentiality is particularly evident in the Gesta Abbatum's portrayals of linguistic ancientness. Its authors were aware that historically contingent language could indicate wider circumstances of composition, making full use of the British book's putative linguistic details to establish its age. Yet beyond this pragmatic exploitation of the vernacular, the Gesta Abbatum also includes a literary depiction of the significance of linguistic mutability. The value of vernacular evidence, marked by time and place, is manifested in the material qualities of the British book. In the moment of its own divinely ordained destruction, it miraculously witnesses the veracity of the British text it contains: paradoxically, it forms an eternal monument to Alban's sanctity through its own ephemerality.

Like other presentations of ancient language at St Albans, the account has been created largely for practical purposes. The authors of the Gesta Abbatum offer a nuanced presentation of British, which systematically employs linguistic detail as a means of grounding the life of Alban in a particular place and time:

Erat enim littera qualis scribi solet tempore quo cives Werlamecestram inhabitabant, et idioma antiquorum Britonum, quo tunc temporis utebantur.[Aliqua tamen in Latino, sed hiis non opus erat.] ${ }^{73}$

For the script was such as was accustomed to be written in the time when people lived in Werlamecestra, and the language was that of the ancient Britons, in which they then spoke. [However, others spoke in Latin, but it was not used in these writings.]

This may betray an awareness of vernacular dialect variations: unlike standardised Latin, the text's British idiom allows its first reader, the priest Unwona, to locate its origin in 'Werlamecestra' or Verulamium, the Roman city of St Albans. ${ }^{74}$ Whilst this emphasis on ancient place names again responded to Geoffrey of Monmouth, in other ways, it sought to 
move beyond British linguistic data to consider the vernacular past as a whole. The text's inclusion of this name was part of its evocation of both English and British vernacular testimony: as well as its references to the British language, it employed the Anglo-Saxon names given by Bede for 'Verulamium', 'which the English now call either Uerlamacestir or Uaclingacastir' ('Uerolamium, quae nunc a gente Anglorum Uerlamacaestir siue Uaeclingacaestir appellatur'). ${ }^{75}$ This willingness to use linguistic detail from both English and British enlarged the work's historical frame of reference. Significantly, at the point when the book was translated by Unwona, an element of linguistic uncertainty appeared: it was now described as written in 'the ancient English, or British language' ('antiquo Anglico, vel Britannico, idiomate'). ${ }^{76}$ The authors of the Gesta Abbatum situated the ancient volume in both ancient Britain and Anglo-Saxon England.

We might see the authors' vagueness about the volume's language as an appeal to the prestige not only of British, but of English historical documents. A closer inspection of other St Albans engagements with the vernacular reveals that Old English texts provided an influential model for depictions of ancient sources. There are further parallels with another St Albans work which employed an equally sophisticated approach to the authenticating power of vernacular language. Writing around II78, William of St Albans created a Latin prose narrative of the martyrdoms of Alban and Amphibalus. ${ }^{77}$ His text was also portrayed as a translation of vernacular source, this time of 'a book written in the English language' ('liber Anglico sermone conscriptus'). ${ }^{78}$ However, William's account introduced a further historical layer: in a second prologue, the English book was in turn depicted as a transcript of writings still visible on the ruins of St Albans. ${ }^{79}$ These writings contained an account of Alban's martyrdom. The English-speaking author in this second prologue was transcribing the Roman text a substantial period later, but still before the widespread conversion of the country to Christianity. Here, the vernacular was used, not to situate the text in the British past of the protomartyr, but to create the voice of a historically authentic witness to the physical evidence remaining of Alban's martyrdom in Anglo-Saxon times. Yet whilst acknowledging the importance of vernacular evidence, both texts did not locate its value in its durability. As with the British book of the Gesta Abbatum, William explained the absence of his Anglo-Saxon narrator's source text through its impending disintegration:

Cives quondam Verolamii, ob elationem cordis sui declarandam qualiter passus sit beatissimus Albanus in muris suae civitatis sculptum reliquerunt: 
quam sc[ul]pturam, longo post tempore, in muris eorum, jam ruinosis et ad ruinam inclinatis, inveni[.] $]^{80}$

The former citizens of Verulamium, in order to make known their hearts' exaltation at the suffering of blessed Alban, left behind engravings on their city walls. I found these carvings long afterward on the same walls, now ruinous and decaying. ${ }^{8 \mathrm{I}}$

By heightening a sense of its antiquity, such a portrayal paradoxically verified the testimony given by the original text even as its self-destruction put it beyond the reach of scholarly enquiry.

These displays of self-consumption challenged some models of textual evidence as eternal witness which were valorised in the cartularies of St Albans. In his study of Anglo-Saxon diplomas, Scott Thompson Smith argues that: 'by making timeless claims for land in a sacred environment, the Anglo-Saxon diploma attempted to fix possession and to refuse changeability, and these affirmations of permanence were driven in part by resilient fears of imminent conflict and reversal'. ${ }^{82}$ The proems to such diplomas often appealed to the durability of the written word, even whilst acknowledging the transience of human possession. ${ }^{83}$ The archive at $\mathrm{St}$ Albans contained a version of this trope in a charter of Æthelred II (dated 996): ${ }^{84}$

Licet regalium dignitatum decreta et antiqua priorum temporum priuilegia permanente integritatis signaculo fixa iugiter ac firma perseuerent, attamen quia plerumque tempestates et turbines seculi fragilem humane uite cursum pulsantes contra superna dominice sanctionis iura illidunt, iccirco stili officio renouanda et cartarum suffragiis sunt roboranda, ne forte successura posterorum progenies, ignorato precedentium patrum cyrographo, inextricabilem horrendi baratri uoraginem incurrat, nec inde libera exire queat donec iuxta ueritatis sententiam cuncta usque ad nouissimum quadrantem debita plenissime reddat.

It is lawful that the royal charters and ancient privileges of former ages shall endure, fixed and affirmed perpetually with the seal of integrity; however, since many storms and whirlwinds of time, battering the fragile course of human life, dash against heavenly laws of sacred binding force, with the help of writing they must therefore be renewed and by means of charters strengthened, lest perhaps future descendants of later generations, having no knowledge of the chirograph of their preceding ancestors, may rush into the inextricable chasm of fearsome hell; nor can they leave free from thence until they shall entirely fulfil the judgement of truth in all debts even unto the last farthing. 
This proem is likely to be genuine, and contains substantial verbal parallels with a diploma of Æthelred's father, Edgar. ${ }^{85}$ Here, the charter was portrayed as the outward sign of an eternal grant to God's church. In spite of the fact that its material form might decay or perish, the property transfer which it recorded remained eternally valid. By echoing the Sermon on the Mount (Matthew 5:25-26), the proem conflated earthly and divine transgression, situating retribution with Christ, the ultimate judge. Probably after IIO7, later readers at St Albans exploited its rhetoric of renewal, inserting a new immunity clause which purported to confirm the privileges contained in an old charter of Offa. ${ }^{86}$ This may have been intended to support wider documentary manipulation: around the same time, the monks fabricated a diploma of Offa from earlier sources, which laid claim to the core endowment of the house. ${ }^{87}$ Yet if these alterations show a belief in the charter as a permanent monument to the monastery's possessions, they also suggest anxiety about the vulnerability of written record to indifference and decomposition. The forgers' actions reflect a wider pattern of late Anglo-Saxon and post-Conquest concerns: from the late tenth century onwards, the extant charters which demonstrated St Albans's title to its contemporary holdings were felt to be insufficient. Noticing that the documents of previous generations had decayed, been destroyed, or simply never been written, the monks decided to supplement the archive with their own creations. They were aware that endurance of the charter as a witness was threatened by dangers of neglect, corrosion, and forgetfulness.

Under these circumstances, the destruction of the British book provides a different perspective on textual instability. Just as the mutability of the vernacular becomes an advantage when locating works in their historical and geographical context, the fragility of the material text also becomes paradoxically advantageous. The Gesta Abbatum offers a fantasy to readers concerned with the preservation of monastic documents. In contrast to charters, the corrosive effects of time do not threaten the witness of the British book. Rather, the very source of its strength lies in its mutable nature. Far from interfering with its ability to testify to God's will, when the British book crumbles to dust, it confirms that its narrative of Alban's life is a divine revelation. The book enacts the value of vernacular impermanence.

\section{Testimony to the Truth: Vernacular Etymologies}

If in many ways the episode of the British book represents the apotheosis of vernacular textuality, the authors of the Gesta Abbatum were also aware 
of the potential of etymological testimony to promote the cult of Alban. In the passage immediately preceding Abbot Eadmer's excavations, they depicted prior archaeological research into ancient Verulamium. This laid the foundations for the British book's later confirmation of Bede's account, but here, the finds were validated by the linguistic witness of local inhabitants. Increasing interest in grounding evidence in a particular period and area transformed perceptions not only of the worth of vernacular written records but also of oral evidence. These re-evaluations of impermanent language encouraged an expansion of the types of vernacular data subjected to scholarly scrutiny, and a modification of the etymological paradigms employed in its interpretation. The vernacular's appeal was situated in the mutability which allowed it to be shaped by its temporal and geographical surroundings.

The Gesta Abbatum stated that Eadmer's predecessor, abbot Ealdred, ordered excavations to be carried out within the remains of the Roman city, based on unspecified antiquae scripturae. The finds included anchors, shells, sand, and parts of ships, suggesting the prior existence of a large body of water. Material evidence was able to establish the authority of earlier martyrdom narratives on Roman Verulamium: the authors commented that the miracle by which the large river became a small one was narrated in full in the Historia de Sancto Albano. ${ }^{88}$ This may have been intended as a reference to Unwona's British book; or to an episode in William's hagiography where the Ver miraculously dries up in response to a prayer from Alban. ${ }^{89}$ Given that, according to Bede, Alban's miracles also involved parting the waters of the river and temporarily relocating it to the top of a hill, the saint's power was rendered far more impressive to a medieval audience by emphasising that the Ver had been navigable in Roman times. ${ }^{90}$ Yet, significantly, a further layer of confirmation was felt to be required. As the excavations continued, the diggers unearthed previously forgotten linguistic tradition:

Unde nomina locis ubi talia repererunt incolae, haec videntes, vel imposuerunt, vel retulerunt se a veteribus relata meminisse: utpote, Oistrehulle, Selleford, et Ancrepol. ${ }^{9 \mathrm{r}}$

When the local inhabitants saw these things, either they bestowed new names on the locations where they had been discovered, or otherwise they were prompted to remember the names they had been told by their forefathers: like Oysterhill, Shelford and Anchorpool.

Matthew Paris seems to have found this passage a convincing demonstration of the longevity of local memory. In his manuscript, he augmented the 
list of names, adding in a marginal gloss: 'Fishpol, - nomen vivarii regii ex reliquiis aque diminute' ('Fishpool - the name of the royal fishpond made out of the remains of the diminished waters').$^{92}$ The evidence of the incolae is only employed as a prelude to the appearance of the British book, suggesting that the volume's miraculous discovery ultimately carries greatest conviction. Yet, if playing a supportive role, oral material is not in competition with the written. Rather, it is uniquely placed to connect text with the historical landscape.

This creative use of oral data to provide geo-historical evidence offers a subtly different perspective on some existing social and epistemological hierarchies. Rather than stressing aristocratic or ecclesiastical authority, it draws more heavily on the perceptions of local knowledge implied by practices of boundary perambulation when delineating estates. Elisabeth van Houts has analysed the widespread use of oral sources in twelfth-century historiography, arguing that authors had a stratified understanding of such testimony. As well as privileging eyewitness accounts, they were also concerned with the status of the witness: information from high-ranking men was preferred. ${ }^{93}$ According to their lowly social status, the oral testimony of peasants should have held little authority. However, the Gesta Abbatum's treatment of vernacular evidence is part of a wider trend which encourages us to re-interpret such testimony. As their ability to move away from a particular estate was often subject to restrictions, peasant language was perceived to have evolved within a specific local area. ${ }^{94}$ This connection to the landscape, stretching back over several generations, was exploited by twelfth-century authors seeking to situate narratives within local geography. Not all chose to convince their readers via an emphasis on the vernacular. Boundary clauses were copied less frequently in the period: although in part, this was due to difficulties or anxieties surrounding the continued comprehension of Old English, other models of linguistic prestige were also available. ${ }^{95}$ However, the use of vernacular evidence from oral sources presented a fundamental challenge to those who thought linguistic expertise to be founded on grammatical and social training. Instead of investing the educated or the aristocratic with the greatest authority, it offered a startlingly egalitarian perspective: knowledge of a given vernacular was available to anyone in contact with the relevant speech community. When employing oral testimony to root historical arguments in a landscape, language which displayed local idiosyncrasies was often more highly prized.

Interest in these idiosyncrasies encouraged a reassessment of previous methods for studying language history, drawing attention to the exegetical opportunities presented by the ephemeral instead of the eternal. As discussed in the introduction, Isidore of Seville remained the central medieval 
authority on Latin etymology, for whom reality was 'primarily a verbal structure which could be comprehended by the analysis of words' ${ }^{96}$ However, not all vocabulary offered the potential for a Neo-platonic recovery of divine intention. Isidore explicitly included vernacular words in his comprehensive catalogue of etymological techniques, although he noted possible difficulties of comprehension:

Sunt autem etymologiae nominum aut ex causa datae, ut 'reges' a regendo et recte agendo, aut ex origine, ut 'homo', quia sit ex humo, aut ex contrariis ut a lavando 'lutum', dum lutum non sit mundum, et 'lucus', quia umbra opacus parum luceat. Quaedam etiam facta sunt ex nominum derivatione, ut a prudentia 'prudens'; quaedam etiam ex vocibus, ut a garrulitate 'garrulus'; quaedam ex Graeca etymologia orta et declinata sunt in Latinum, ut 'silva', 'domus'. Alia quoque ex nominibus locorum, urbium, vel fluminum traxerunt vocabula. Multa etiam ex diversarum gentium sermone vocantur. Unde et origo eorum vix cernitur. Sunt enim pleraque barbara nomina et incognita Latinis et Graecis.

Etymologies of words are furnished either from their rationale, as 'kings' from ['ruling' and] 'acting correctly'; or from their origin, as 'man' because he is from 'earth', or from the contrary, as 'mud' from 'washing', since mud is not clean, and 'grove', because, darkened by its shade, it is scarcely 'lit'. Some are created by derivation from other words, as 'prudent' from 'prudence'; some from sounds, as 'garrulous' from 'babbling sound'. Some are derived from Greek etymology and have a Latin declension, as 'words', 'home'. Other words derive their names from names of place, cities, [or] rivers. In addition, many take their names from the languages of various peoples, so that it is difficult to discern their origin. Indeed, there are many foreign words unfamiliar to Latin and Greek speakers. (I.xxix.3-5)

Amidst this extensive list, Isidore left no place for the derivation of words created 'by whim' ('secundum placitum'), arguing that: 'etymologies are not to be found for all words, because some things received names not according to their innate qualities, but by the caprice of human will' ('omnium nominum etymologiae non reperiuntur, quia quaedam non secundum qualitatem, qua genita sunt, sed iuxta arbitrium humanae voluntatis vocabula acceperunt', I.xxix.2-3). He did not explain why such coinages were unsuitable for etymological scrutiny: presumably because, rather than offering insights into the divine force which shaped both word and referent in Eden, they instead reflected only human concerns.

When exploring vernacular data, the emphasis of etymological study was altered. Rather than seeing names created in recent historical circumstances as ephemeral and hence unworthy of analysis, such names became 
a central scholarly focus. The transience of vernacular language rendered them uniquely valuable, because they recorded local responses to specific events. This type of etymology was particularly common in hagiographical and historical writing, drawing on pre-Conquest insular interpretative traditions. ${ }^{97}$ When reworking an earlier Hiberno-Latin life of St Modwenna, Geoffrey of Burton was at pains to emphasise that his additions reflected the 'trustworthy and reliable report of truthful men, who had knowledge of them from their elders or witnessed them at first hand' ('ueracium ualde uirorum, qui uel didicerunt a maioribus uel ipsi uiderunt atque affureunt presentes, fidelissima et probatissima narracione'). ${ }^{98}$ His source, Conchubranus, had described the miraculous resurrection of a drowned girl through the intercession of St Modwenna, as witnessed by nearby shepherds. ${ }^{99}$ Geoffrey retained the account, but was careful to include a further passage which described the oral dissemination of the story, and its subsequent etymological commemoration:

Diuulgatum est autem circumquaque istud tam grande miraculum, prius quidem per ora pastorum qui presentes fuerant ac deinde relacionibus quam plurimorum, et fluuius in quo uirgo submersa est Anchora dicitur et illa pars aque ubi ceciderat, quia fuerat sanctimonialis Osid, ad testimonium ueritatis $\mathrm{ab}$ incolis loci illius sermone publico usque hodie Nunnepol appellatur.

Reports of this great miracle spread far and wide, first from the mouths of the shepherds who were present and in the accounts of many others. The river in which the virgin drowned is called the Anker and, because Osgyth was a nun, that part of it where she fell is still called 'Nun's Pool' to this day by the inhabitants of the place as testimony to the truth. ${ }^{100}$

The appeal of etymology lay in its ability to transform each member of its audience into a type of eyewitness: we can confirm the author's etymological interpretation through our own knowledge of the word under discussion. Geoffrey's consideration of this place name was able to demonstrate something more. Like the authors of the Gesta Abbatum, who depicted the locals bestowing new names on places found in the course of the excavations, he assumed that toponyms were often created to mark noteworthy occurrences. Here, twelfth-century audience members beyond the immediate vicinity of the river Anker may well have been unable to verify the etymology through their general knowledge. ${ }^{\text {IOI }}$ However, by using the testimony of local inhabitants, Geoffrey could provide a group of contemporary witnesses whose knowledge was strengthened by a substantial linguistic inheritance: their authority stemmed from the length of their ancestral association with the land. Not only did the incolae attest to the persistence 
of the name into the twelfth century; they affirmed that their predecessors thought Osgyth's rescue from the waters sufficiently miraculous to mark the spot with a new toponym. This kind of etymology does not directly pursue the recovery of an atemporal, divine truth through close linguistic analysis. Rather, it reconstructs the climate of local wonder prompted by the miracle as historical occurrence. Although this helps to verify that the event took place, which in turn vouchsafes the presence of God on earth, its primary goal is to situate a particular event in time.

Whilst these employments of etymology to recreate the temporally particular sought to modify trans-historical trajectories of language, other aspects of the Isidorean legacy remained influential. In their use of vernacular evidence to substantiate broader arguments, twelfth-century authors were closely informed by contemporary interest in etymology as a technique for rhetorical exegesis. Peter Helias (c.IIOO-c.II66) wrote:

Ethimologia ergo est expositio alicuius vocabuli per aliud vocabulum, sive unum, sive plura magis nota, secundum rei proprietatem et litterarum similitudinem ut 'lapis' quasi 'ledens pedem', 'fenestra' quasi 'ferens nos extra'. Hic enim et rei proprietas attenditur et litterarum similitudo observatur. ${ }^{\mathrm{IO} 2}$

Therefore, etymology is the exposition of one word through another word or words which are more familiar, according to the property of the thing and the similarity of letters, such as stone, as it were wounding the feet, window, as it were carrying us outside. Here indeed, the property of the thing is respected and the similarity of letters is observed. ${ }^{103}$

This model continued to follow Isidore by stressing the elucidation of a word's divine inner force (vis): deriving etymology from ethimos (true) and logos (word), Peter noted that 'he who etymologises describes the true, that is the first, origin of the word' ('qui ethimologizat veram, id est primam, vocabuli originem assignat'). ${ }^{104}$ However, his emphasis on exposition and association shows a growing sense of the ways in which etymology could also be used to provoke new perspectives.

Increasingly, lexical study was seen as a mechanism as much for generating eloquence as linguistic investigation. Peter's definition has been influenced by the grammatical technique of derivation (derivatio): already outlined by Isidore, in the twelfth century this was seen as part of, or related to, the discipline of etymology. The technique aimed 'to create families of terms, of which one was considered as the original and all the others as "derivations" or terms derived from the original one'. ${ }^{\text {Ios }}$ In his influential 
Liber derivationum, Osbern of Gloucester ( $f$ l.II48) provided a characteristic treatment of rivus:

Rivus vi, inde hic rivulus li, et rivosus a um, et hic rivalis is .i. ille qui cum alio tenet unam uxorem, unde Terentius in eunucho militis ego rivalem recipiendum censeo. Et per compositionem derivo as, unde derivator, derivatus, derivatio, et derivatim adverbium, sicut dicimus hec pars derivatim dicitur $\mathrm{ab}$ illa .i. secundum ordinem derivandi. Item ab hoc nomine quod est rivus et pluraliter hi renes num quia ab eis rivi cenosi humoris dirivantur, et inde hic renunculus li diminutivum, et his reno nis .i. pellicia circa renes, et hoc renale is .i. zona circa renes, et hic rien enis .i. porcellus. ${ }^{106}$

Rivus, -vi ('river'), whence rivulus, -li ('rivulet'), and rivosus, -a, -um ('endowed with streams'), and rivalis, -is ('rival'), which is one who shares a wife with another, hence Terence in The Eunuch: 'I suggest [you] accept the rival of the soldier'. And through compounding: derivo, -as ('I derive'), whence derivator ('deriver'), derivatus ('derived'), derivatio ('derivation'), and the adverb derivatim, just as we say 'this word is said derivatively from that', i.e. according to the order of deriving. Also from the noun rivus, in the plural: renes, -num ('kidneys'), because from them the filthy streams of humour are drawn off, and whence as a diminutive renunculus, -li ('a little kidney'), and reno, -nis ('a fur garment'), which is a thing made of skins [wrapped] around the kidneys, and renale, -is ('renal'), which is the area around the kidneys, and rien, -enis, which is a piglet.

Osbern's presentation of the allusive connections between words created several pathways in parallel, which did not direct readers to any single perspective. Instead, his work aimed to facilitate interpretative plurality. The prologue stated that although beginners may select 'slight and scarce words' ('tenues [...] et perraras partes'), experts would 'extend themselves in multiple streams in multiple ways of deriving' ('in multiplices se derivandi rivos multipliciter extendunt'). ${ }^{107}$ Rather than depicting the linear development of lexis, derivatio provided a rhetorical method of linking several ideas and arguments together through language. This form of verbal exegesis was less concerned with tracing historical filiation, than with composition.

The production of twelfth-century vernacular etymologies was therefore poised between sensitivity to the historical specificity of language, and awareness of the discursive possibilities afforded by linguistic interpretation: whilst etymological data could afford unique insights into popular perceptions of language history, it was equally shaped by the imperatives of clerical narration. In one sense, the depiction of language in the Gesta Abbatum exemplified the ways in which the study of vernacular linguistic 
history offered a counterpoint to presentations of the past which emphasised the timeless exemplarity of God's providential plan. ${ }^{\text {I08 }}$ The British language attested to the Roman date of the Vita of St Alban; the historical witness of place names was confirmed, not via the Edenic reverberations contained in Isidorean etymologies, but in peasant memory. Yet this historicity was complicated by a simultaneous awareness of linguistic exegesis as a site for ludic, rhetorical constructions of meaning. Even whilst appealing to the authoritative testimony of ancient languages, the Gesta Abbatum unravelled this authority by raising doubts over the relationship between linguistic interpretation and desire: etymology, like the discovery of ancient writings, was driven by the demands of imagination as much as fact.

The last place name given in this passage of the Gesta Abbatum explores the tension between exposition and rhetorical extrapolation: as with the British book, this episode provides a commentary on the emotional motivations which influence the writing of history. The place names remembered by the locals impressively substantiate archaeological discovery, connecting the newly uncovered landscape to communal memories of the ancient past. But the final English toponym supplied in this context exposes the extent to which such names arre based on hopes for a type of evidence capable not only of corroborating, but of penetrating and illuminating the historical subject. We are told that during his excavations, Abbot Ealdred found the subterranean remnants of Verulamium to be a haunt of thieves and prostitutes. He therefore decided to raze as much of the remains as was practicable, although retaining any Roman materials suitable for ecclesiastical construction projects. The last vernacular name provided in the passage occurs in this context, when the abbot discovers the signs of an abandoned dragon's lair:

Specum quoque profundissimum, monte continuo circumseptum, cum spelunca subterranea, quam quondam draco ingens fecerat et inhabitavit, in loco qui 'Wormenhert' dicitur, in quantum potuit, explanavit; vestigia tamen aeterna habitationis serpentinae derelinquens. ${ }^{109}$

Also he flattened (insofar as he could) the deepest cave, enclosed by the unbroken rock, with the underground den which once a huge dragon had made and inhabited, in the place which is called 'Wormenhert'; but he left behind the still-remaining traces of a serpent's dwelling.

Isidorean etymology purports to reveal the 'innate qualities' ('qualitatem, qua genita sunt') of any given object. ${ }^{\text {IIO }}$ Ealdred's entry into the deepest cave mirrors this process of etymological penetration. His archaeological act rejects the recovery of material evidence in favour of the linguistic. 
Here, the word itself becomes an artefact. He emerges not only with knowledge of the serpent's den, but with a rationale for its name: the dragon can now be shown to have lived at the heart of the hill. If the historical impulse behind etymological enquiry is dramatised here, the authors did not directly employ etymological methods to elucidate the connection between the dragon's cave and its name. Rather, readers must analyse its onomastic significance for themselves, recreating Ealdred's prior act of toponymic recovery. Other aspects of the name's origins remain suggestively ambiguous: the reasons behind the decision to call the cave 'Wormenhert' are left opaque. Although this could be a freshly bestowed name, the text leaves open the possibility that Ealdred's discoveries has prompted the locals to recollect another archaic epithet previously used by their ancestors. The vernacular is depicted as a repository of material which is both tangibly connected to a semi-fabulous past, and latent in the most ancient recesses of the landscape: etymological investigation proves capable of bringing to light names and things which previously appeared to be buried beyond the reach of memory. Yet as coincidences and correspondences accrue, the narrative's comprehensive fulfilment of the demands of linguistic recovery raises questions concerning its status as fact or fiction. In providing a total (rather than partial) verification of the St Albans past, the authors surpass the limited parameters of what can be verified historically: instead, the narrative becomes what ought to have been true. The more successful the abbot's investigations, the greater our suspicions of the account's veracity become. The Gesta Abbatum emphasises the tension between a wish to believe in comprehensive linguistic proof, and the extent to which such credulity can be stretched: it offers a too-perfect correspondence between the type of historical arcana we desire, and that which is supplied. If the account's improbabilities invite us to fantasise about language's power to recover the seemingly lost, they also invite us to consider the implications of our own enjoyment of such historically improbable details. The authors require us not only to be complicit in their fantasy of linguistic recovery, but to explore the reasons why we would wish to be so. Vernacular language history provides a site to evaluate motivations for the creation and consumption of imaginative literature.

Portrayals of Britain's vernaculars offered authors a way to manifest the concerns which lay behind a growing interest in history and written records in the twelfth century. In discussing the motivations behind the sudden florescence of miracle collecting in the post-Conquest era, Rachel Koopmans has rejected the premise that a written dossier was necessary to secure the status of native saints. Rather, she suggests that the compilers of the 
seventy-five or so surviving collections were more concerned with potential forgetfulness: 'What they were seeking to defend themselves against with these texts, it appears, was the weight of time and the fragility of human memory'. ${ }^{\text {III }}$ Anxiety over the endurance of remembrance rendered the past a burden: the compilation of cartularies, the creation of histories, the search for ancient source texts and the tracing of vernacular etymologies all provide examples of the ways in which the twelfth century was preoccupied with loss. Yet whilst monastic authors were most vocal in their awareness of the precarious nature of transmitting past traditions, they also tacitly took advantage of the opportunities destruction brought to re-shape institutional legacies. The earliest major post-Conquest historian, Eadmer (c.1060-II26 or after) wrote an elegiac description of Anglo-Saxon England, enumerating the pre-Conquest cathedral church at Canterbury as he knew it as a small boy before its destruction by fire in 1067. But his poignant reconstruction of a vanished era also provided a crucial excuse for the absence of Christ Church's ancient charters, supposedly destroyed in the blaze. ${ }^{\mathrm{II} 2}$ Between $107 \mathrm{O}$ and II23 a series of forged papal letters and privileges were created in the monastery, designed to cement its claim to primacy over every church in Britain. ${ }^{\mathrm{II} 3}$ They were included by Eadmer as part of an extended assertion of Canterbury's rights in his Historia novorum in Anglia: while he may or may not have known of their provenance, the scriptorium more widely did not scruple to take advantage of their purported archival losses to fabricate new texts. ${ }^{\mathrm{II}} 4$ The interpretation of Britain's linguistic history in the St Albans Gesta Abbatum was situated at the centre of this awareness of the issues and options created by decay. Its authors explored the dual need to preserve the past, and to present it to future generations. The vernacular provided a locus for thinking about change: although language could be interpreted as a penitential exemplar of eternal mutability, its instability also allowed writers to consider the different ways in which this historically contingent material could be deployed to situate texts in specific time periods, or in a more mythical past. As with earlier insular scholarship, twelfth-century portrayals of Britain's linguistic history were hence almost never straightforward attempts to recover the verbal testimony of previous ages. Instead, creative concerns intersected with the factual, as authors interpreted the vernacular in the light of ambitions, disappointments, and dreams. 